\title{
Multicentre Study of a New Enzymatic Method of Cholesterol Determination
}

\section{By R. Kattermann}

Klinisch-Chemisches Institut, Klinikum Mannheim der Universität Heidelberg, Mannheim

D. Jaworek and G. Möller

Boehringer Mannheim GmbH, Biochemica Forschungszentrum Tutzing, Abteilung Evaluierung, Tutzing

in collaboration with

\section{G. Assmann}

Zentrallaboratorium der Medizinischen Einrichtungen der Westfälischen Wilhelms-Universität, Münster

I. Björkhem and L. Svensson

Karolinska Institut, Department of Clinical Chemistry, Huddinge

K. Borner

Institut für Klinische Chemie und Klinische Biochemie der Freien Universität Berlin, Klinikum Steglitz, Berlin

G. Boerma and B. Leijnse

Akademisch Ziekenhuis, Rotterdam-Dijkzigt, Department of Clinical Chemistry, Rotterdam

\section{J. P. Desager and C. Harwengt}

Laboratory of Pharmacotherapy of the University of Leuven, Brussels

Irene Kupke

Medizinische Einrichtungen der Universität, Zentralinstitut für Klinische Chemie und Laboratoriumsdiagnostik, Düsseldorf and

\section{P. Trinder}

District General Hospital, Department of Biochemistry, Sunderland

(Received September 9/Novembệ 19, 1983)

Dedicated to Professor Dr. Dr. h.c. W. Creutzfeldt, Göttingen, on the occasion of his 60th birthday

Summary: A new enzymatic method for the determination of cholesterol in serum and plasma was evaluated in 8 separate laboratories in comparison with routine and reference methods.

Investigation of the analytical reliability in the $2-26 \mathrm{mmol} / \mathrm{l}$ measurement range showed the following results:

1. At the set reading points $\left(10 \mathrm{~min}\right.$ at $25^{\circ} \mathrm{C}$ and $5 \mathrm{~min}$ at $\left.37^{\circ} \mathrm{C}\right)$ the reaction shows complete substrate conversion. The colour complex is stable over a period of $60 \mathrm{~min}$.

2. The response to cholesterol is linear up to $26 \mathrm{mmol} / \mathrm{l}$.

3. Precision within the series was $0.6-2.8 \%$ in 20 determinations (coefficient of variation). 
4. Day to day precision was $0.5-3.3 \%$ in triple determinations of 10 days (coefficient of variation).

5. Accuracy was studied with 2 samples (assigned value: 3.52 and $6.70 \mathrm{mmol} / 1$ respectively). In the case of sample 1 the mean for the 8 laboratories was 3.44 , with a median of 3.44 ; for sample 2 the values were 6.68 and 6.72 .

The results demonstrate an excellent transferability.

6. In comparison with other enzymatic procedures, the values found with the new test were $5-10 \%$ higher; these results agree at all concentration ranges with the reference methods of $A$ bell \& Kendall and with those from mass spectrometry.

\section{Multizentrische Erprobung einer neuen enzymatischen Cholesterinbestimmung}

Zusammenfassung: Eine neue enzymatische Methode zur Bestimmung des Cholesterins in Serum und Plașma wurde in 8 Laboratorien im Vergleich zu Routine- und Referenzmethoden evaluiert.

Die Ưberprüfung der analytischen Zuverlässigkeit ergab im Meßbereich zwischen 2 und $26 \mathrm{mmol} / \mathrm{l}$ folgende Ergebnisse:

1. Der Reaktionsverlauf zeigt zu den angegebenen Ablesezeitpunkten $\left(25^{\circ} \mathrm{C}: 10 \mathrm{~min}\right.$ und $\left.37^{\circ} \mathrm{C}: 5 \mathrm{~min}\right)$ vollständigen Substratumsatz und innerhalb von 60 min gute Stabilität des Farbkomplexes.

2. Bis zu $26 \mathrm{mmol} / \mathrm{l}$ wird das Cholesterin linear erfaßt.

3. Präzision in der Serie von $0,6-2,8 \%$ bei 20 Bestimmungen (Variationskoeffizient).

4. Präzision von Tag zu Tag von $0,5-3,3 \%$ bei 3 fach-Bestimmungen an 10 Tagen (Variationskoeffizient).

5. Prüfung auf Richtigkeit mit 2 Proben (Zielwert: 3,52 bzw. 6,70 mmol/l). Bei Probe 1 betrug der Mittelwert der 8 Laboratorien 3,44 und der Median 3,44, bei Probe 2 6,68 und 6,72.

Diese Ergebnisse zeigen die sehr gute "Transferabilität" des Testes in den verschiedenen Laboratorien.

6. Im Vergleich mit anderen enzymatischen Verfahren wurden mit dem neuen Test 5-10\% höhere Werte, mit den Referenzmethoden nach Abell \& Kendall sowie der Massenspektrometrie übereinstimmende Ergebnisse in allen Konzentrationsbereichen gefunden.

\section{Introduction}

The determination of cholesterol for the diagnosis and therapy of metabolic disorders and diseases has long been an important feature of the clinical-chemical laboratory. As a result, a large number of analytical methods based on the colour complex formation of cholesterol as an indicator reaction have been described in the literature (1). The processes employ highly caustic chemicals and are characterised, in addition to the non-specificity of the reaction, by a high susceptibility to failure and a wide range of errors; hence many study groups have been working to replace this chemical procedure with simple, quick and exact methods of analysis.

The first enzymatic processes were developed in $1972(2-4)$ : these used cholesterol oxidase to convert cholesterol into cholestenone and $\mathrm{H}_{2} \mathrm{O}_{2}$, following alkaline saponification or enzymatic splitting of the cholesterol ester.

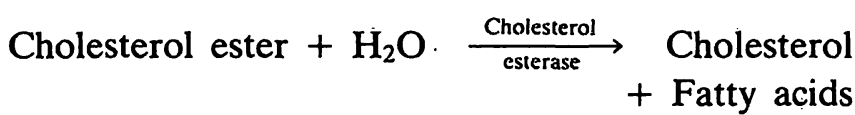

Cholesterol $+\mathrm{O}_{2} \underset{\text { oxidase }}{\stackrel{\text { Cholesterol }}{\longrightarrow}} \Delta^{4}$-Cholestenone $+\mathrm{H}_{2} \mathrm{O}_{2}$.

In the reaction known as the 'catalase method' formaldehyde was formed from the $\mathrm{H}_{2} \mathrm{O}_{2}$ with methanol in the presence of catalase; this formaldehyde. was converted with ammonium ions and acetylacetone into 3,5-diacetyl-1,4-dihydrolutidine. The resultant colour was measured in the $400 \mathrm{~nm}$ wavelength range $(5,6)$.

By combining this with the process developed by Trinder, the conversion of $\mathrm{H}_{2} \mathrm{O}_{2}$ with phenol and 4aminoantipyrine into a quinoneimine colour complex, the incubation and rection times of the enzymatic cholesterol determination could be markedly shortened and the practicability of the test was further improved $(7,8)$. 
In comparison with the reference method $(9,10)$ these enzymatic processes showed on average 4-6\% lower cholesterol values (11), which suggests an incomplete splitting of the cholesterol ester $(12-14)$. To improve the splitting of the cholesterol ester Boehringer Mannheim isolated new esterases, and these were optimised into a new test in conjunction with the phenol/4-aminoantipyrine indicator system. The test available under the trademark 'Monotest ${ }^{\circledR}$ Cholesterol High Performance' has the same characteristics as the monotest available up to the present, but as a result of its complete splitting of the cholesterol ester, shows a very good agreement with the cholesterol values obtained with the reference methods.

The present report describes a multicentre study of this new test.

\section{Materials and Methods}

The sample material was obtained from the laboratories of each of the participants. The control serum used for verification was provided by Boehringer Mannheim.

The final concentration of substrates, enzymes and detergents are shown in Table 1.

Tab. 1. Reagents in the new Monotest ${ }^{\otimes}$ Cholesterol High Performance.

\begin{tabular}{ll}
\hline Components & $\begin{array}{l}\text { Final } \\
\text { concentrations }\end{array}$ \\
\hline
\end{tabular}

Tris-HCl buffer, $\mathrm{pH} 7.7$

4-Aminophenazone

Phenol

3,4-Dichlorophenol

Sodium cholate

Fatty alcohol polyethylene glycol ether

Cholesterol esterase

Cholesterol oxidase

Peroxidase
$100 \mathrm{mmol} / \mathrm{l}$

$1 \mathrm{mmol} / \mathrm{l}$

$6 \mathrm{mmol} / 1$

$6 \mathrm{mmol} / \mathrm{I}$

$10 \mathrm{mmol} / \mathrm{l}$

$3 \mathrm{~g} / \mathrm{l}$

$0.4 \mathrm{kU} / \mathrm{l}$

$0.25 \mathrm{kU} / \mathrm{l}$

$0.20 \mathrm{kU} / \mathrm{l}$

The procedural instructions sent to all participants contained data for the manual implementation of the test as summarised below:

Sample material:

Sample volume:

Reagent volume:

Principle of measurement:

Incubation time:

Wavelength:

Calculation:

The reference methods followed by the external laboratories were carried out in accordance with the published procedures $(16,17)$.
The testing of the new enzymatic cholesterol followed the program below:

1. Determination of precision within the series and from day to day using the pool of serum produced by the laboratory itself at three different levels of concentration. The determination of precision within the series was carried out by means of $20 \mathrm{de}-$ terminations from one pool; the determination of day to day precision was in triple determinations over 10 days.

2. The accuracy study was conducted in triple determinations on 5 days with 2 control samples of serum. The target values for the samples were 3.52 for $P_{1}$ and $6.70 \mathrm{mmol} / \mathrm{l}$ for $P_{2}$.

3. The linearity of measurement range study was carried out using a human serum with a high cholesterol concentration; this was mixed with a $9 \mathrm{~g} / \mathrm{l}$ sodium chloride solution in an 11 -step dilution sequence and analysed in double determinations.

4. For comparison of methods, the determination procedures customarily used in the individual laboratories were used; these were predominantly mechanised methods.

\section{Results and Discussion}

\section{Reaction kinetics}

The participants in the trial monitored the course of the reaction of the test material with sera of different cholesterol concentrations over a period of $60 \mathrm{~min}$ utes. As the records of the changes over time of the measurement signal show (fig. 1), a stable end product was obtained at the recommended reading time of $10 \mathrm{~min}$ at $25^{\circ} \mathrm{C}$

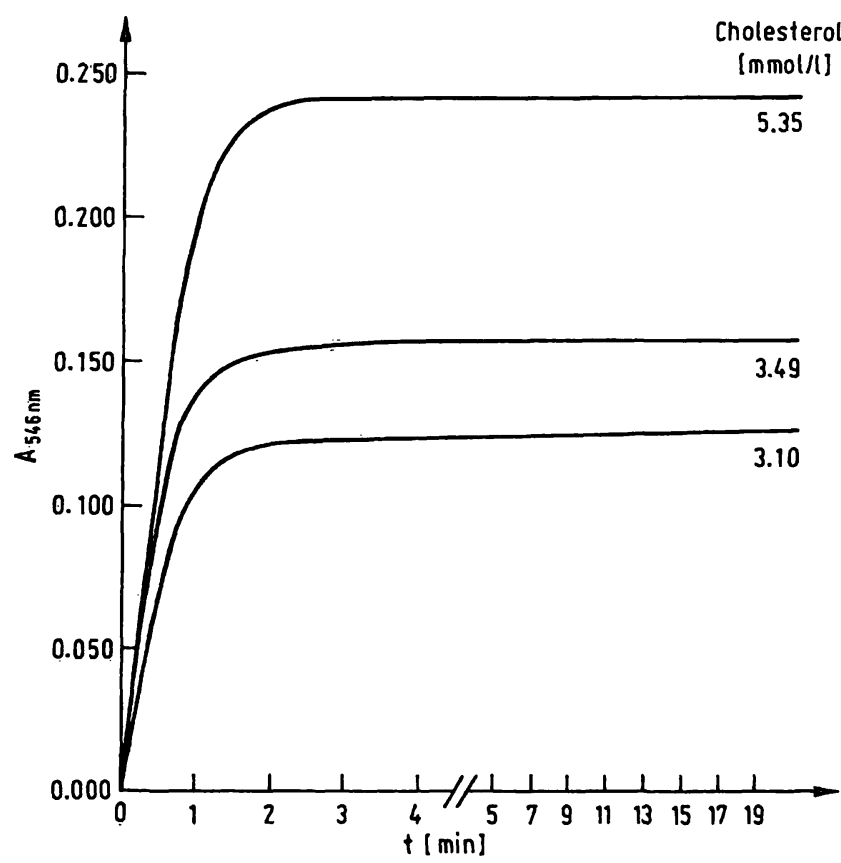

Fig. 1. Progress of the reactions of new Monotest ${ }^{\otimes}$ Cholesterol High Performance with human sera. Temperature $25^{\circ} \mathrm{C}$. A dilution series consisting of several steps was performed from a human serum of a predetermined cholesterol concentration. 


\section{Linearity and range of measurement}

To study the linearity range, all participants used human sera with a high cholesterol content diluted with $9 \mathrm{~g} / \mathrm{l}$ sodium chloride and analysed using various types of apparatus under different reaction and measurement conditions. As the results summarised in figure 2 show, the measurement range of the new enzymatic test produced linear results, without dilution of the sample, up to concentrations as high as 26 $\mathrm{mmol} / \mathrm{l}$.

\section{Precision}

The determination of precision within the series and from day to day was conducted in 3 concentration ranges and was characterised by figures for coefficients of variation. The data presented in tables 2 and 3 show coefficients of variation of $0.6-2.2 \%$ for measurements within the series and $0.5-3.3 \%$ for measurements from day to day.

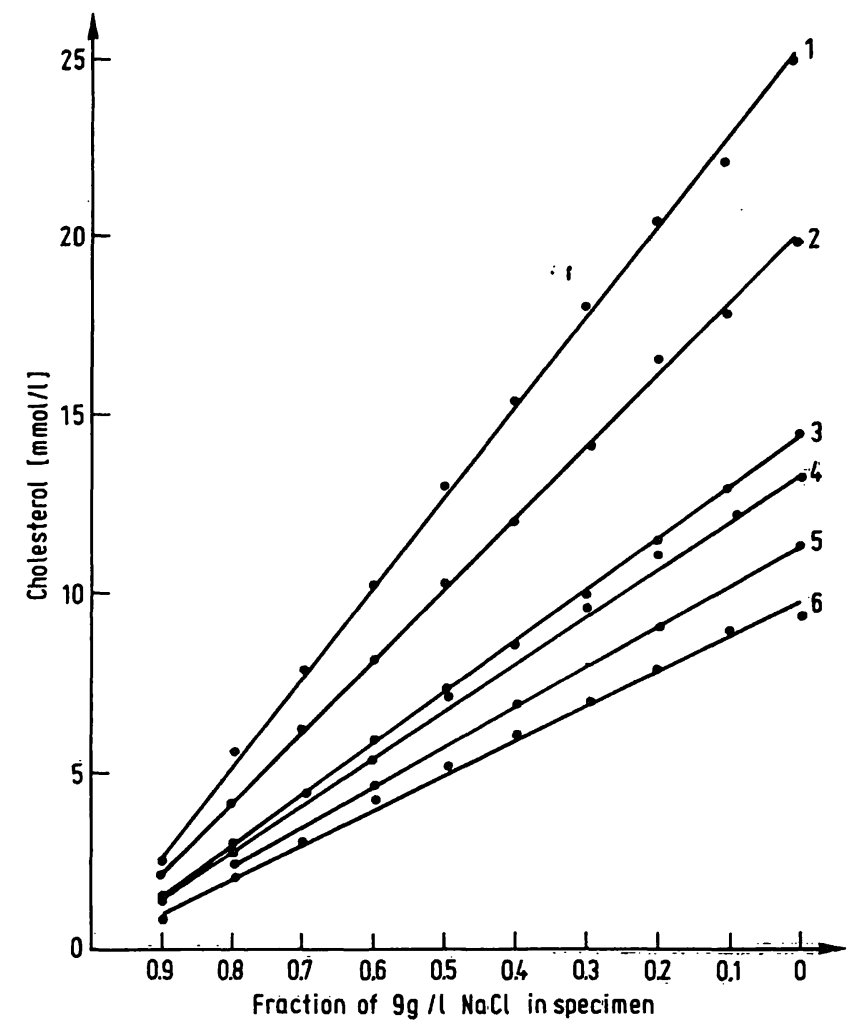

Fig. 2. Linearity, measured using different types of apparatus:
1. Eppendorf ACP 5040
4. Technicon AA-II
2. Hitachi 706
5. Gilford 3500
3. Technicon AA-II

Tab. 2. Precision within the series. Measurements by the participants: in each case 20 determinations with human serum with 3 different cholesterol concentrations. $c_{1}, c_{2}$ and $c_{3}$.

\begin{tabular}{|c|c|c|c|c|c|c|}
\hline \multirow[b]{2}{*}{ Apparatus } & \multicolumn{2}{|c|}{$c_{1}$} & \multicolumn{2}{|c|}{$c_{2}$} & \multicolumn{2}{|c|}{$c_{3}$} \\
\hline & $\begin{array}{l}\overline{\mathrm{x}} \\
(\mathrm{mmol} / \mathrm{l})\end{array}$ & $\begin{array}{l}\text { VK* } \\
(\%)\end{array}$ & $\begin{array}{l}\overline{\mathbf{x}} \\
(\mathrm{mmol} / \mathrm{l})\end{array}$ & $\begin{array}{l}\text { VK* } \\
(\%)\end{array}$ & $\begin{array}{l}\overline{\mathrm{x}} \\
\cdot(\mathrm{mmol} / \mathrm{l})\end{array}$ & $\begin{array}{l}\text { VK* } \\
(\%)\end{array}$ \\
\hline Eppendorf-Photometer & 2.84 & 1.7 & 5.43 & 2.0 & 10.72 & 1.1 \\
\hline Hitachi 706 & 3.85 & 0.8 & 5.97 & 2.0 & 8.81 & 1.6 \\
\hline LKB-Ultrolab-System & 3.93 & 0.6 & - & - & 8.01 & 0.5 \\
\hline Chemetrix & 3.26 & 1.4 & 6.05 & 2.8 & 9.56 & 2.5 \\
\hline Gilford-3500 & 3.15 & 1.3 & 5.99 & 1.1 & 9.17 & 1.2 \\
\hline LKB-Ultrolab-System & 3.67 & 2.2 & 6.54 & 1.8 & 9.77 & 0.9 \\
\hline Technicon AA-II & 3.77 & 1.6 & 6.69 & 1.0 & 10.0 & 0.9 \\
\hline
\end{tabular}

$* \mathrm{VK}=$ coefficient of vatiation

Tab. 3. Precision from day to day. Measurements by the participants: in each case 3 determinations on 10 days with human serum with 3 different cholesterol concentrations, $c_{1}, c_{2}$ and $c_{3}$.

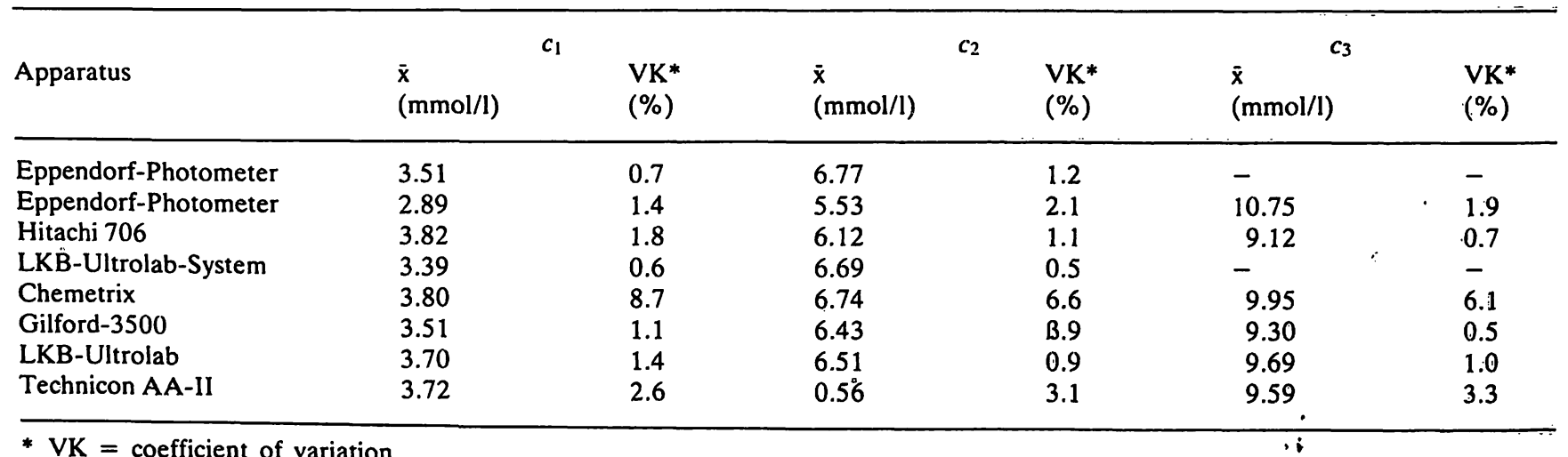

* VK $=$ coefficient of variation 


\section{Collaborative test for accuracy check}

Two quantities of control sera, which were determined in an internal ring trial by the new Monotest ${ }^{\circledR}$ cholesterol High Performance, were sent to the participants. In order to check the accuracy of the new cholesterol test; they were asked to determine the cholesterol content of each sample. In sample $P_{1}$ the mean value for cholesterol was 3.44 , and the median was 3.44 ; the assigned ('correct') value was 3.52 $\mathrm{mmol} / \mathrm{l}$. In sample $P_{2}$ the assigned value was 6.70 ; values of $6.68 \mathrm{mmol} / \mathrm{l}$ were obtained for the mean and 6.72 for the median. The deviations between the assigned values and sample values were $0.08 \mathrm{mmol} / \mathrm{l}$ for sample $P_{1}$ and 0.02 for sample $P_{2}$, corresponding to a relative variation of $2.3 \%$ and $0.3 \%$ respectively.

\section{Comparison of methods}

For purposes of comparison, the participants included enzymatic methods and established chemical and physico-chemical methods (which served as reference methods).

A comparison of the new monotest with other enzymatic methods clearly showed higher cholesterol values at all concentration ranges; the means of the relative differences lie in the range -1 to $+10 \%$ (see tab. 4).

Comparison with gas chromatography/mass spectrometry performed by $I$. Björkhem et al. (16) and the reference methods of $A$ bell et al. performed by G. Boerma et al. (9) showed good agreement with measured values (see tab. 5). In comparison with the new enzymatic test, the reference methods gave values that were $1 \%$ higher. This may be regarded as good agreement with the enzymatic method.

In the context of an extended field trial, further enzymatic methods and the reference method of $A$ bell et al. (9) were compared with the new test. These field studies once again confirmed the results of the test for enzymatic methods and gave a variation of $-1 \%$ to $+1 \%$ (17) for the reference method of Abell et al.

Tab. 4. Comparison of Monotest ${ }^{\circledR}$ Cholesterol High Performance with other enzymatic methods').

\begin{tabular}{|c|c|c|c|c|c|c|c|}
\hline \multirow{2}{*}{$\begin{array}{l}\text { Method } \mathrm{I}^{2} \text { ) / Apparatus } \\
\text { Hitachi-706 }\end{array}$} & \multirow{2}{*}{$\begin{array}{l}\left.\text { Method } \mathrm{II}^{3}\right) ;{ }^{4} \text { ) } \\
\text { CHOD/PAP, BM }\end{array}$} & \multirow{2}{*}{$\begin{array}{l}\text { Apparatus } \\
\text { Hitachi-706 }\end{array}$} & \multicolumn{2}{|c|}{$\begin{array}{l}\text { Paired Slope b } \\
\text { values }\end{array}$} & \multicolumn{2}{|c|}{$\begin{array}{l}\text { Axis intercept a } \\
(\mathrm{mmol} / \mathrm{l})\end{array}$} & \multirow{2}{*}{$\begin{array}{l}\text { Mean relative } \\
\text { differences } \\
(\%)\end{array}$} \\
\hline & & & 70 & 0.937 & -0.034 & 0.997 & \\
\hline Hitachi-706 & CHOD/PAP, BM & Technicon SMAC & 70 & 0.929 & +0.086 & 0.997 & +4.3 \\
\hline Eppend.-Photom. 6115 & CHOD/PAP, BM & Epp.-Photom. 6116 & 60 & 0.985 & +0.082 & 0.998 & +0.2 \\
\hline Eppend.-Photom. 6115 & CHOD/PAP, BM & Hitachi-712 & 59 & 1.001 & -0.577 & 0.959 & +9.6 \\
\hline Chemetrix & CHOD/PAP & Chemetrix & 60 & 1.128 & -1.11 & 0.986 & +5.1 \\
\hline Eppend., Apparatus 5031 & CHOD/PAP, BM & Eppend., App. 5031 & 50 & 0.927 & +0.115 & 0.992 & +4.8 \\
\hline Eppend., Apparatus 5031 & CHOD/PAP, BM & Technicon SMA 12 & 50 & 0.951 & +0.036 & 0.995 & +5.1 \\
\hline Eppend.-Photom. 6115 & Catalase Method & Epp.-Photom. 6115 & 60 & 0.918 & +0.065 & 0.994 & +7.0 \\
\hline LKB-Ultrolab-System & CHOD/PAP, BM & LKB-Ultrolab-System & 60 & 1.038 & -0.093 & 0.984 & -1.1 \\
\hline Technicon, AA-II & CHOD/PAP्P, BM & Technicon AA-II & 60 & 0.944 & +0.307 & 0.981 & +0.2 \\
\hline
\end{tabular}

1) Mean geometric analysis of regression (18).

2) Method I = Monotest ${ }^{\circledR}$ Cholesterol High Performance.

3) $\mathrm{CHOD} / \mathrm{PAP}=$ Cholesterol oxidase/4-aminophenazone-method.

4) $\mathrm{BM}=$ Boehringer Mannheim.

Tab. 5. Comparison of Monotest ${ }^{\circledR}$ Cholesterol High Performance with chemical and physico-chemical methods of determination ').

\begin{tabular}{|c|c|c|c|c|c|c|}
\hline Method $I^{2}$ ) / Apparatus & Method II / Apparatus & $\begin{array}{l}\text { Paired } \\
\text { values } n\end{array}$ & Slope b & $\begin{array}{r}\text { Axis i } \\
(\mathrm{mmol} / \mathrm{l}\end{array}$ & tercept a & $\begin{array}{l}\text { Mean relative } \\
\text { differences } \\
(\%)\end{array}$ \\
\hline $\begin{array}{l}\text { LKB-Ultrolab-System } \\
\text { Eppend.-Photom. } 6115 \\
\text { LKB-Ultrolab-System }\end{array}$ & $\begin{array}{l}\text { Mass-spectrometry-ionisation detection } \\
\text { Extraction procedure according to } A \text { bell et al. } \\
\text { Extraction procedure according to } A \text { bell et al. }\end{array}$ & $\begin{array}{l}11 \\
60 \\
60\end{array}$ & $\begin{array}{l}0.973 \\
1.023 \\
1.064\end{array}$ & $\begin{array}{l}+0.153 \\
-0.054 \\
-0.235\end{array}$ & $\begin{array}{l}0.998 \\
0.993 \\
0.984\end{array}$ & $\begin{array}{l}-0.6 \\
-1.4 \\
-1.2\end{array}$ \\
\hline
\end{tabular}

1) Mean geometric analysis of regression (18).

2) Method I = Monotest ${ }^{\star}$ Cholesterol High Performance. 
As this comparison of methods with commercially available enzymatic procedures and with reference methods has shown, higher cholesterol values are found with the new enzymatic test, which is conducted using an esterase isolated from a strain of Pseudomonas. This is correlated with improved hydrolysis of the ester, as confirmed in recent studies (15).

\section{Conlcusion}

Investigations under external test conditions have led to the recommendation that this new enzymatic test, which has excellent transferability, be proposed as a candidate for a reference method, since the method is quick and simple to use and can be adopted immediately by any laboratory.

The trial participants have combined this recommendation with the requirement that the Monotest ${ }^{\circledR}$ Cholesterol High Performance be checked against the 'Primary Reference Method' at intervals and on a batch unit basis, so that this test can then be put forward as a secondary reference method for routine laboratory purposes.

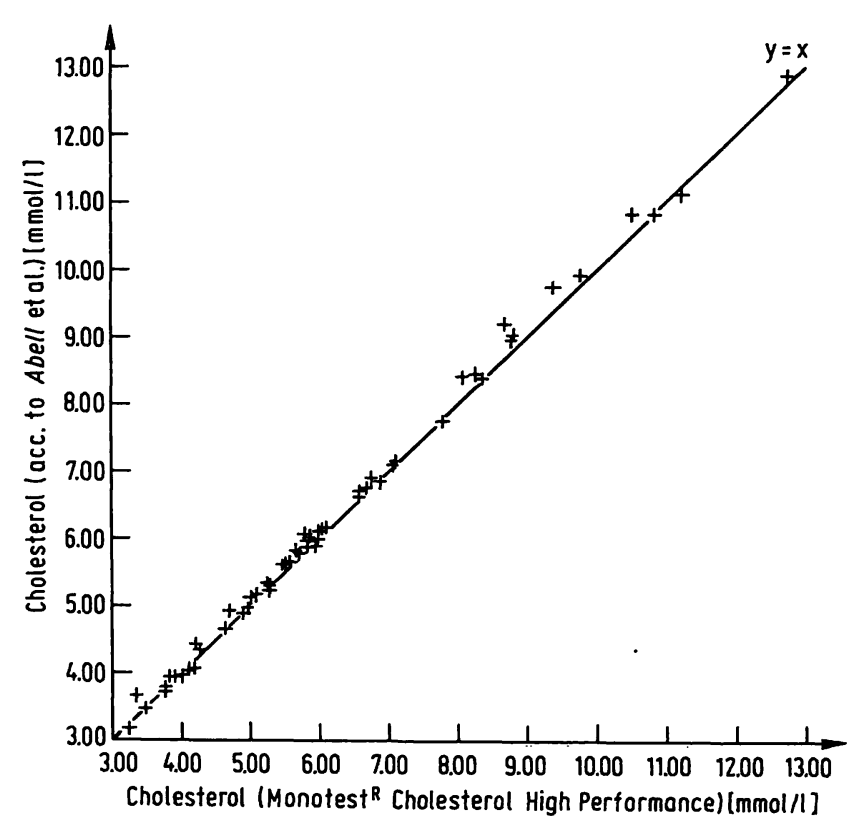

Fig. 4. Comparison of methods: Monotest (1) Cholesterol High Performance (x) and the reference method of Abell et al. (y).

- $\mathrm{N}=59 ;$ slope $\mathrm{b}=1.064 ;$ axis intercept $\mathrm{a}=0.235 \mathrm{mmol} / \mathrm{l}$ Correlation coefficient $\mathrm{r}=0.984$.

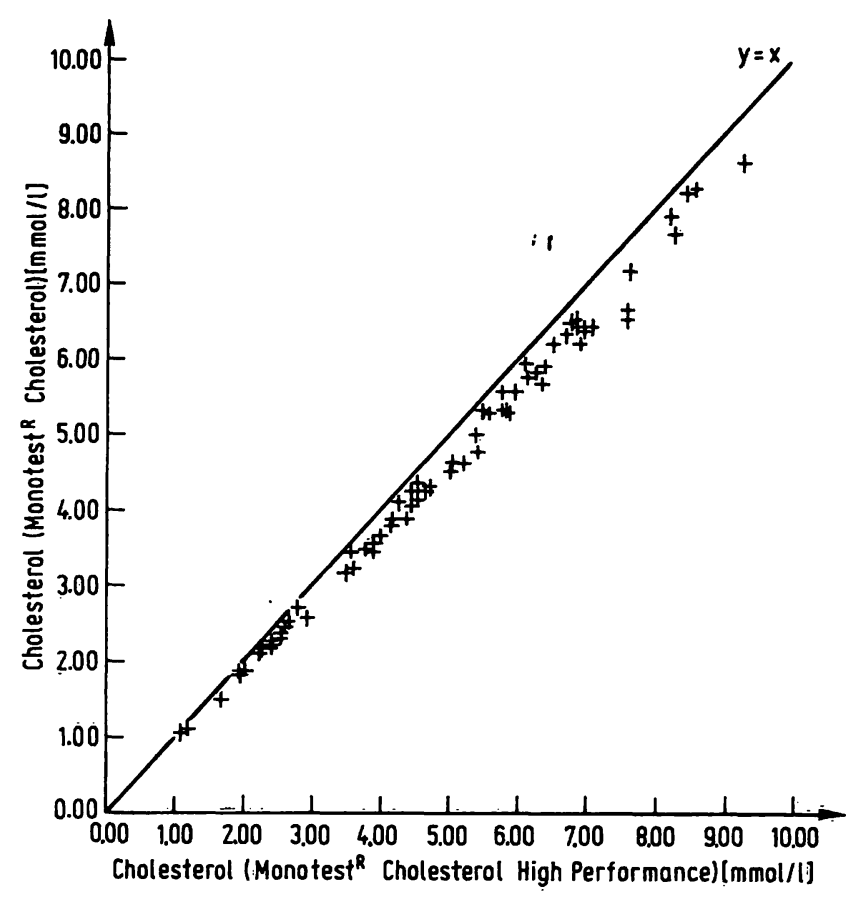

Fig. 3. Comparison of methods: Monotest ${ }^{\circledR}$ Cholesterol High Performance $(x)$ and the Monotest in current use $(y)$. $\mathrm{N}=70$; slope $\mathrm{b}=0.04$; axis intercept a $=-0.037 \mathrm{mmol} / \mathrm{l}$ Correlation coefficient $r=0.998$.

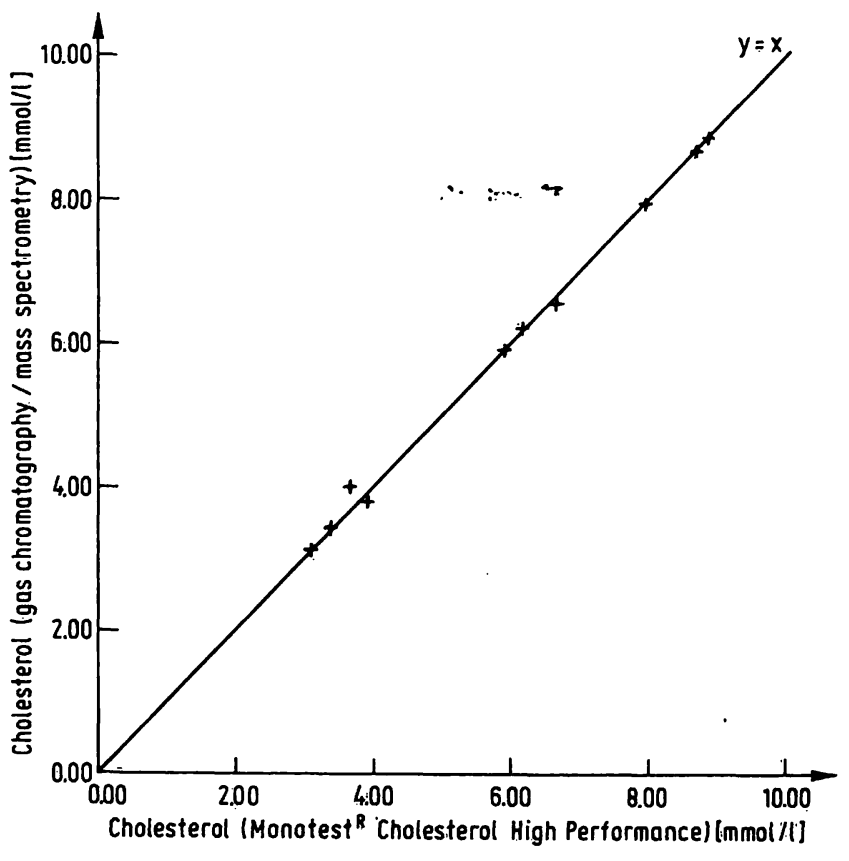

Fig. 5. Comparison of methods: Monotest ${ }^{\circledR}$ Cholesterol High Performance $(x)$ and the gas chromatography/mass spectrometry reference method $(y)$.

$N=10$; slope $b=0.975$; axis intercept $a=0.153$ Correlation coefficient $\mathrm{r}=0.998$. 


\section{References}

1. Zak, B. (1977) Clin. Chem. 23, 1201-1214.

2. Richmond, W. (1972) Scand. J. Clin. Lab. Invest. 29, suppl. 126.

3. Flegg, H. M. (1973) Ann. Clin. Biochem. 10, 79-84.

4. Roeschlau, P., Bernt, E. \& Gruber, W. (1974) In: Methoden der enzymatischen Analyse (Bergmeyer, H.-U., ed.), pp. 1938-1941, Verlag Chemie, Weinheim.

5. Roeschlau, P., Bernt, E. \& Gruber, W. (1974) Z. Klin. Chem. Klin. Biochem. 12, 403-407.

6. Kageyama, N. (1971) Clin. Chim. Acta 31, 421-426.

7. Trinder, P. A. (1969) Ann. Clin. Biochem. 6, 24-27.

8. Stähler, F., Gruber, W., Stinshoff, K. \& Röschlau, P. (1977) Med. Lab. 30, 29-37.

9. Abell, L. L., Levy, B. B., Brodie, B. B. \& Kendall, E. E. (1952) J. Biol. Chem. 195, 357-366.

10. Siekmann, L., Mackrodt, D., Röhle, G. \& Breuer, H. (1983) Dt. Ges. f. Klin. Chemie - Mitteilungen 14, 16-18.

11. Cooper, G. R. (1978) Clin. Chem. 25, 1074.
12. Cooper, G. R., Dundan, P. H., Hazlehurst, J. S., Miller, D. T., Bayse, D. D., Widdowson, G. M., Mulvihill, H. J., Kuehnemann, M. L., Kupke, I., Zeugner, S. \& Driscoll, J. L. (1981) Selected Methods of Clinical Chemistry for a Small Volume Laboratory (Faulkner, W. R. \& Meites, S. M., eds.) Volume 9, pp. 165-174.

13. Tel, R. M. \& Berend, G. T. (1980) J. Clin. Chem. Clin. Biochem. 18, 595-601.

14. Kattermann, R., Kupke, I. \& Borner, K. (1983) J. Clin. Chem. Clin. Biochem. 21, 347-355.

15. Siedel, J., Haegele, E. O., Ziegenhorn, J. \& Wahlefeld, W. (1983) Clin. Chem. 29, 1075-1080.

16. Björkhem, I. (1974) Clin. Chim. Acta 54, 185-193.

17. Ludewigs, M. (1982) Test report "Monotest ${ }^{\circledR}$ Cholesterol High Performance", Boehringer Mannheim, 23.

18. Averdunk, R. \& Borner, K. (1970) Z. Klin. Chem. Klin. Biochem. 8, 263-268.

Dr. D. Jaworek

Boehringer Mannheim $\mathrm{GmbH}$

Biochemica Forschungszentrum Tutzing

Abteilung Evaluierung

Postfach 1263/64

D-8132 Tutzing

Prof. Dr. R. Kattermann

Klinisch-Chemisches Institut

Klinikum der Stadt Mannheim

Postfach 23

D-6800 Mannheim 
. 